\title{
EFFECT OF HEALTH EDUCATION ON FOOT EXERCISE IN PATIENTS WITH TYPE II DIABETES MELLITUS AT GRATI FAMILY CLINIC, PASURUAN, EAST JAVA
}

\author{
Tavip Dwi Wahyuni'1), Fiashriel Lundy²) \\ School of Health Polytechnics, Ministry of Health, Malang, East Java
}

\begin{abstract}
Background: Diabetes is a major public health problem that is approaching epidemic proportions globally. Worldwide, the prevalence of chronic, noncommunicable diseases such as diabetes is increasing at an alarming rate. About 18 million people die every year from cardiovascular disease, for which diabetes is a major predisposing factor. Gymnastics can help improve blood circulation and strengthen the small muscles of the foot so as to prevent foot deformities. Gymnastics overcome the limitations of joint movement that is often experienced by clients with type 2 diabetes mellitus (type $2 \mathrm{DM}$ ). Health education motivates a person to receive health information and do according to the information so that they become more knowledgeable and healthier. This study aimed to analyze the effect of health education on the practice of foot exercise in patients with type 2 diabetes mellitus.
\end{abstract}

Subjects and Method: This was a randomized controlled trial conducted at Grati Family Clinic, Pasuruan, East Java, from January to March 2015. A sample of 60 patients with type 2 DM was randomized into two groups: (1) 30 patients received health education of foot exercise; (2) 30 patients did not receive health education of foot exercise. The dependent variable was foot exercise. The independent variable was education about foot exercise. The data were collected by questionnaire and observation. Percent difference of patients practicing foot exercise in the two groups was tested by Chi-square.

Results: After health education, the percentage of type 2 DM patients who practice the foot exercise in the health education group $(n=17 ; 56.7 \%)$ was higher than the non health education group $(n=4 ; 13.3 \%)$, and it was stasticallly significant $(\mathrm{p}<0.001)$. Type $2 \mathrm{DM}$ patients who participated in the health education session were eight times more likely to practice foot exercise than patients who did not participate $(\mathrm{OR}=8.50 ; \mathrm{p}<0.001)$.

Conclusion: Health education session is effective in increasing the number of type $2 \mathrm{DM}$ patients to practice foot exercise.

Keywords: health education, foot exercise, type 2 diabetes mellitus

\section{Correspodence:}

Tavip Dwi Wahyuni. School of Health Polytechnics, Ministry of Health, Malang, East Java. Email: tavipdwiwahyuni@gmail.com. Mobile: 08125210202. 